\title{
KAJIAN PENERAPAN TUGAS MINI RISET TERHADAP HASIL BELAJAR MAHASISWA MATERI KEANEKARAGAMAN HAYATI
}

\author{
Abdul Hakim Daulae ${ }^{*}$, Lazuardi, Martina A. Napitupulu \\ Program Studi Pendidikan Biologi, FMIPA, Universitas Negeri Medan \\ Jl. Williem Iskandar Psr. V Medan Estate, Medan, Indonesia, 20221 \\ *email abdulhakimdaulae@unimed.ac.id
}

\begin{abstract}
ABSTRAK
Penelitian ini bertujuan menemukan data empiris tentang penerapan tugas mini riset terhadap hasil belajar mahasiswa pada mata kuliah Biologi Sistem di lingkungan FMIPA Unimed Medan pada tahun pembelajaran 2017/2018 dengan materi Keanekaragaman Hayati . Metode yang digunakan dalam penelitian ini adalah quasi experiment dengan desain nonequivalent control group design. Dari hasil penelitian menunjukkan kemampuan mahasiswa dalam penguasaan materi keanekaragaman hayati yang diberikan tugas dengan mini riset pada nilai (post-test) lebih tinggi dengan nilai rata-ratanya (95) dibandingkan kelas kontrol (70). Selain itu, penguasaan keterampilan komunikasi secara tertulis, keterampilan presentasi lisan, keterampilan analisis/ berpikir kritis dan keterampilan integrasi lebih tinggi dari kelas kontrol. Dengan demikian dapat dikatakan bahwa penerapan tugas mini riset pada mahasiswa yang mengikuti mata Kuliah Biologi Sistem di lingkungan FMIPA Unimed dapat meningkatkan hasil belajarnya dalam penguasaan materi pelajaran Keanekaragaman hayati. Demikian juga dapat meningkatkan kemampuan mahasiswa dalam penguasaan keterampilan komunikasi secara tertulis, keterampilan presentasi lisan, keterampilan analisis/ berpikir kritis dan keterampilan integrasi. Hasil penelitian ini akan dijadikan perbaikan buku pedoman pembelajaran Biologi Dasar di lingkungan FMIPA Unimed.
\end{abstract}

Kata kunci: Mini riset, Keanekaragaman hayati, Hasil belajar mahasiswa

\section{ABSTRACT}

This study aims to find empirical data about the application of mini research tasks to student learning outcomes in the course of Systems Biology at FMIPA Unimed Medan. The method used in this research is quasi experiment with nonequivalent control group design. The results showed that students' ability in mastery of biodiversity material given task with mini research on value (post-test) was higher with mean value (95) than control class (70). In addition, the mastery of communication skills in writing, oral presentation skills, skills of analysis / critical thinking and integration skills is higher than the control class. Thus it can be said that the application of mini research tasks to students who follow the course of Systems Biology in FMIPA Unimed can improve learning outcomes in the mastery of biodiversity lesson materials. Likewise can improve the ability of students in the mastery of communication skills in writing, oral presentation skills, skills of analysis / critical thinking and integration skills. The results of this study will be used as a refinement of Basic Biology learning guide in FMIPA Unimed.

Keywords: Mini research, Biodiversity, Student learning outcomes 


\section{PENDAHULUAN}

Pada Mata Kuliah Biologi System telah disusun capaian pembelajaran anatara lain mahasiswa bertaqwa kepada Tuhan Yang Maha Esa, memiliki moral, etika dan kepribadian yang baik di dalam menyelesaikan tugasnya, Mampu bekerja mandiri dan bekerja sama dengan orang lain dalam melaksanakan tugas, Mampu mengkomunikasikan ide dan informasi secara lisan ataupun tulisan serta meningkatkan kemampuan profesionalnya secara berkelanjutan, menguasai konsep biologi untuk pengembangan ilmu pengetahuan dan pembelajaran, Mampu mengaplikasikan konsep biologi menyelesaikan persoalan-persoalan aktual yang relevan dengan biologi.

Selama ini mahasiswa telah diberikan pembelajaran berbagai macam metode pembelajaran untuk mencapai tujuan pembelajaran. Akan tetapi dalam hal materi pembelajaran keanekaragaman hayati masih terlihat kurang memuaskan. Hal ini dapat dilihat dari capaian nilainya masih $70 \%$ yang baik hal ini masih rendah dalam menghayati arti dan makna keanekaragaman hayati.

Keanekaragaman hayati merupakan salah satu sumber kehidupan bagi manusia yang hidup di muka bumi ini. Selain memenuhi kebutuhan pokok seperti pangan, sandang dan papan, biodiversitas juga memenuhi kebutuhan sekunder, seperti tempat rekreasi (Sastrapradja \& Widjaja, 2010).

Sejalan dengan itu maka dipandang perlu mahasiswa diberikan tugas yang dapat mengemban capaian tersebut, satu diantara tugas yang dapat mengemban capaian tersebut adalah dengan melaksanakan tugas mini riset. Selama ini pembelajaran Biologi System belum mengaplikasikan model tugas Mini riset pada materi ini. Model pembelajaran ini memiliki keunggulan diantaranya membuat mahasiswa menjadi lebih aktif dan berhasil memecahkan masalah yang kompleks.

Untuk itu perlu inovasi dalam hal meningkatkan hasil belajar mahasiswa yang mengikuti perkuliahan Biologi dasar dengan memberikan tugas mini riset agar mahasiswa kedepannya dapt berfikir kritis dan inovatif serta memunculkan nilai-nilai seperti an akan dicapai oleh mata kuliah ini. Pada saat sekarang ini mahasiswa harus dapat mngungkapkan fakta baru demi terwujudnya kepribadian yang mandiri dan mampu bekerja sama dengan temannya inilah yang akan dimunculkan pada saat melakukan mini riset.

Salah satu teori pembelajaran untuk dapat menguasai konsep atau materi adalah dengan konstruktivisme, yaitu filosofi belajar yang menekankan bahwa belajar tidak hanya sekedar menghafal, tetapi mengkonstruksi atau membangun pengetahuan dan keterampilan baru, lewat fakta-fakta yang mereka alami dalam kehidupannya (Muslich, 2008). Salah satu model pembelajaran konstruktivisme adalah pembelajaran mini riset.

Mengingat belum pernahnya diteliti tentang pelaksanaan tugas mini riset di jurusan Biologi FMIPA Unimed, maka pada saat ini peneliti memandang sangat perlu untuk melakukan penelitian ini. Pada penenitian ini dibatasi hanya dilakukan pada mahasiswa yang mengikuti Mata Kuliah Biologi System. Mnini riset hanya pada materi Keanekaragaman Hayati yang meliputi Flora dan Fauna.

Adapun tujuan penelitian ini adalah untuk mendapatkan data empiris penerapan tugas mini riset terhadap hasil belajar mahasiswa MK Biologi System materi Keanekaragaman Hayati.dan untuk mengetahui berapa besar pengaruh penerapant tugas mini riset terhadap hasil belajar mahasiswa MK Biologi System materi Keanekaragaman Hayati.

Manfaat yang diharapkan dari penelitian ini adalah: Sebagai masukan bagi Jurusan Biologi FMIPA UNIMED untuk dapat meningkatkan hasil belajar mahasiswa dan sebagai bahan masukan bagi dosen MK Biologi System untuk memperbaiki buku panduan berikutnya.

Untuk mengetahui pengaruh tugas mini riset ini terhadap penguasaan konsep biologi keanekaragaman hayati (biodiversitas), teknik pengolahan datanya menggunakan $u j i \mathrm{t}$ yang berasal dari tes objektif. Uji $t$ tersebut pada prinsipnya adalah membandingkan rata-rata hasil tes objektif antara kelas perlakuan dan kelas kontrol. 


\section{METODE PENELITIAN}

Metode yang digunakan dalam penelitian ini adalah quasi experiment dengan desain nonequivalent control group design, seperti pada Gambar 1.

Tabel 1. Desain Penelitian

\begin{tabular}{cccc}
\hline & Pretest & Perlakuan & Posttest \\
\hline Kelas Kontrol & T1 & X1 & T2 \\
Kelas Eksperimen & T1 & X2 & T2 \\
\hline
\end{tabular}

Keterangan:
T1= Pretest Materi Biologi Keanekaragaman
T2 = Posttest Materi Biologi Keanekaragaman
X1 = Pembelajaran Diskusi
X2 = Pembelajaran dengan tugas Mini Riset

Subyek dalam penelitian ini adalah mahasiswa yang mengikuti Mata Kuliah Biologi System di lingkungan FMIPA Unimed yang terdiri dari dua kelas. Satu kelas sebagai eksperimen dan kelas yang satu laginya menjadi kelas kontrol. Masing-masing kelas terdiri dari 40 orang mahasiswa. Lokasi Mini Riset dilaksanakan pada daerah areal kampus dan disekitar tempat tinggal mahasiswa yang ada di Provinsi Sumatera Utara.

Instrumen yang digunakan adalah soal tes objektif untuk mengukur kemampuan mahasiswa dalam menguasai konsep biologi keanekaraman hayati. Tes objektif disusun dengan indikator yang meliputi pengetahuan tentang prinsip dan proses ekologi yang berhubungan dengan biodiversitas, pengetahuan tentang permasalahan dan isu-isu yang berhubungan dengan keanekaraman hayati, dan pengetahuan tentang strategi dan aksi penyelamatan keanekaraman hayati.

Untuk mengetahui pengaruh tugas mini riset ini terhadap penguasaan konsep biologi keanekaragaman hayati (biodiversitas), teknik pengolahan datanya menggunakan uji $t$ yang berasal dari tes objektif. Uji $t$ tersebut pada prinsipnya adalah membandingkan rata-rata hasil tes objektif antara kelas perlakuan dan kelas kontrol.

\section{HASIL PENELITIAN}

Dari hasil penelitian menunjukkan kemampuan mahasiswa dalam penguasaan materi keanekaragaman hayati yang diberikan tugas dengan mini riset (kelas Eksperimen) mendapatkan nilai pada post-test lebih tinggi dengan nilai rataratanya 95 dibandingkan kelas kontrol 70 . Selain itu, kemampuan penguasaan penerapan keterampilan komunikasi secara tertulis, keterampilan presentasi lisan, keterampilan analisis/ berpikir kritis dan keterampilan integrasi lebih tinggi dari kelas kontrol.

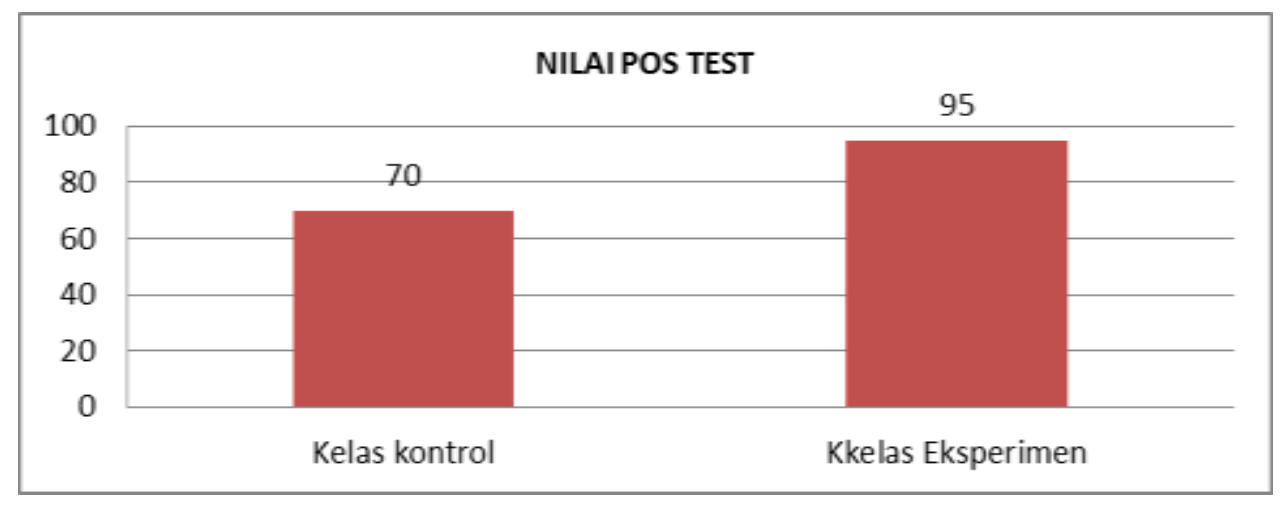

Gambar 1. Perbandingan Kemampuan Mahasiswa pada Kelas Kontrol dan Kelas Eksperimen 
Setelah dilakukan uji beda rata-rata (uji t) menunjukkan hasil bahwa terdapat perbedaan peningkatan penguasaan materi mahasiswa antara kelas eksperimen dengan kelas kontrol (Gambar 1). Hal ini dapat diketahui bahwa pembelajaran dengan mini riset pada mata kuliah Bio Dasar mempunyai pengaruh peningkatan penguasaan materi pelajaran.

Pada pembelajaran di Mata Kuliah Bio Dasar yang disertai dengan tugas mini riset akan memunculkan pembelajaran aktif di kelas dan akan disertai pengamatan langsung ke lapangan. Menurut pendapat Dahar (2011) berusaha sendiri untuk mencari pemecahan masalah serta pengetahuan yang menyertainya, menghasilkan pengetahuan yang benar-benar bermakna. Jika kita menerapkan pembelajaran siswa aktif untuk menemukan konsep dan prinsip melalui pengalaman melakukan pengamatan, investigasi dan percobaan-percobaan akan meningkatkan kemampuan mahasiswa itu untuk menguasai materi pembelajaran.

Dalam mata kuliah Bio Dasar dengan materi keanekaragaman hayati akan memberi kontribusi dalam peningkatan penguasaan materi dalam pembelajaran. Hal ini akan memberikan pendekatan kontektual. Pendekatan kontekstual menurut Suyanti (2010) peserta didik belajar mengalami sendiri, dan tahu untuk apa dia belajar dan bagaimana ia menggunakan pengetahuan dan keterampilan yang dia peroleh.

Pada pendekatan kontekstual ini, prinsip konstruktivisme, bertanya dan menemukan merupakan rangkaian yang menyebabkan meningkatnya pengetahuan peserta didik. Pengetahuan dan keterampilan yang diperoleh peserta didik bukan berasal dari menginggat seperangkat fakta-fakta, tetapi hasil dari menemukan sendiri, melalui observasi, bertanya, mengajukan hipotesis, mengumpulkan data, dan menyimpulkannya.

Menurut Trianto (2009) prinsip inkuiri merupakan kunci untuk meningkatkan pengetahuan peserta didik. Prinsip tersebut meliputi merumuskan masalah, mengobservasi, menganalisis dan menyajikan hasilnya dalam bentuk tulisan, gambar, grafik, tabel dan karya lainnya, serta mengomunikasikan hasil temuannya.
Menurut Glynn dan Winter (2004), pembelajaran kontekstual menuntut kolaborasi antar siswa, menggunakan konteks dunia nyata dan integrasi berbagai ilmu, sehingga akan berpengaruh terhadap penguasaan konsep peserta didik.

Pada hasil penelitian ini juga didukung penelitian yang sebelumnya dan sudah dilakukan diantaranya Suroso (2016) memperoleh data dengan mini riset dapat meningkatkan hasil belajar mahasiswa, demikian juga Puput dkk (2014) terdapat peningkatan hasil belajar mahasiswa dan keterampilan dengan mini riset

\section{KESIMPULAN}

Dengan menerapkan pembelajaran mahasiswa pada mata kuliah Bio System di lingkungan FMIPA Unimed disertai tugas mini riset daalam materi Keanekaragaman hayati dapat meningkatkan kemampuan penguasaan hasil belajar mahasiswa pada kelas dengan tugas mini riset dengan nilai rata-rata 95. Kemampuan penguasaan penerapan keterampilan komunikasi secara tertulis juga meningkat, keterampilan presentasi lisan, keterampilan analisis/ berpikir kritis dan keterampilan integrasi juga meningkat selanjutnya dapat mengubah sikap, kecakapan, nilai, perilaku dan keyakinan mahasiswa terhadap alam, yang pada akhirnya dapat tercipta mahasiswa yang berkarakter peduli lingkungan dan memiliki jiwa peneliti kemasa depan. Saran dalam penelitian ini agar diterapkannya mini riset pada mata kuliah Biologi Sistem di lingkungan FMIPA Unimed daalam materi Keanekaragaman hayati

\section{DAFTAR PUSTAKA}

Dahar, R.W. (2011). Teori-Teori Belajar. Jakarta: Penerbit Erlangga.

Glynn, S.M \& Winter, L.K. (2004). “Contextual Teaching and Learning of Science in Elementary Schools". Journal of Elementary Science Education. 16, (2) : 51-63.

Muslich, M. (2008). KTSP Pembelajaran Berbasis Kompetensi Dan Kontekstual. Jakarta: PT Bumi Aksara. 
Puput Irawaty Sembiring Hasruddin, dan Binari. (2014). ManurungEfektivitas Penggunaan Buku Mini Riset Mikrobiologi Terapan Pada Hasil Belajar Pratikum dan Keterampilan Proses Sains Mahasiswa. Prodi Pendidikan Biologi Program Pascasarjana Universitas Negeri Medan.

Sastrapradja, S.D. \& Widjaja, E.A. (2010). Keanekaragaman Hayati Pertanian Menjamin Kedaulatan Pangan. Jakarta: LIPI Press.

Suyanti, R.D. (2010). Strategi Pembelajaran Kimia. Yogyakarta: Graha Ilmu.

Trianto. (2007). Model Model Pembelajaran Inovatif Berorientasi Konstruktivistik, Konsep Landasan Teoritis

Suroso, ML. (2016). Pengaruh Pembelajaran Mini Riset Berbasis Kearifan Lokal Terhadap Kemampuan Penguasaan Materi Biologi Konservasi. Proceeding Biology Education Conference (ISSN: 2528-5742), Vol 13(1) 2016: 575-578. 